\title{
The Effect of Psychological Factors on Entrepreneurial Intention
}

\author{
K. Kurjono*, H. Mulyani, Y. Murtadlo \\ Universitas Pendidikan Indonesia \\ Bandung, Indonesia \\ *kurjono@upi.edu
}

\begin{abstract}
The low intention of student entrepreneurship has an impact on unemployment. Assessing the intention of entrepreneurship is important because students when graduated are required to create jobs. Lecturers must be able to analyze and review psychological aspects because it will increase entrepreneurial intentions. The purpose of this study is to find out how the influence locus of control, risk-taking and confidence in entrepreneurial intentions and gender roles, so that in what variables are dominant of increasing entrepreneurial intentions. The grand theory of this research is the TPB theory of Ajzen. The research method used is Explanatory Survey Method. The study sample was 377 respondents. Data collection uses a Likert scale questionnaire. Data processing techniques using path analysis. The results of the study showed that locus of control and confidence together had a positive effect on Entrepreneurial Intention. Confidence has the biggest influence on entrepreneurial intention. Based on the results of these studies it is suggested that increasing the variable locus of control, especially in indicators of lack of effort and increase the variable confidence in the indicator of the ability to start a business.
\end{abstract}

Keywords-Psychological Factor; Entrepreneurial Intention; Locus of Control

\section{INTRODUCTION}

The increasing number of entrepreneurs is inseparable from the role of education. Therefore the role of entrepreneurship education is very important in the development of the country. Given that entrepreneurship can be taught, the need for entrepreneurship education in the curriculum at every level of education is

It is widely recognized both on the European continent. According to [1] the focus of research on entrepreneurship education, there seems to be a research gap in the initial steps of students in the "path of entrepreneurial rise" and awareness of entrepreneurship. [2] state that the ultimate goal in entrepreneurship education programs is to prepare people for career success and increase their capacity to learn in the future. [3] found that participants who participate in companies foster a positive attitude can show greater potential than nonparticipants.

\section{METHOD}

The study was conducted from May to November 2018 in the University of Indonesia's environment, J1 Dr. Setiabudi No 229 Bandung 40154. The study population was 19,919 with a sample size of 377 respondents. The data collection technique is a questionnaire (questionnaire), to obtain data relating to the entrepreneurial intentions of the indicators: independent business lines, entrepreneurial careers and business planning. Locus of control indicators: confident in their abilities, like working hard, lacking in effort and lacking in initiative. Taking risk indicators: self-confidence, the ability to look for opportunities, willingness to be able to gain profit and be able to assess risks realistically. Confidence in the indicators: selfmanaging business, resource leadership and the ability to start a business Questionnaires are arranged using attitude scales with interval data types. Analysis techniques use path analysis. Before testing hypotheses, the hypothesis requirement test is carried out first, consisting of a normality test, autocorrelation and homogeneity test. Based on path analysis, the structural model of this study is described as follows:

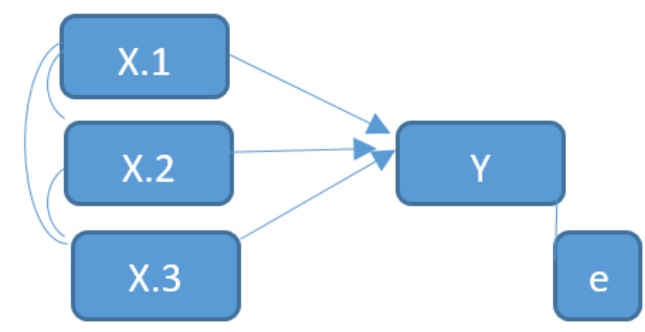

Figure 1. The initial structure of the research model.

$$
\begin{aligned}
& \text { X.1 }=\text { Locus of control } \\
& \text { X.2 }=\text { Risk-taking } \\
& \text { X.3 }=\text { Confidence } \\
& \text { Y }=\text { Entrepreneurial intention } \\
& \text { e. }=\text { Other factors not examined }
\end{aligned}
$$


While the influence of locus of control and confidence in Entrepreneurial Intentions is explained in table 3 as follows:

The condition of each exogenous variable. locus of control is $66.58 \%$ in moderate conditions, the highest indicator is trust in its abilities, while the lowest is lack of effort. Risk-taking is $75.67 \%$ in high conditions, the highest indicator is confidence seeking opportunities while the lowest is confidence in yourself. Confidence of 81.10 in high conditions the highest indicator is self-confidence in managing a business, while the lowest is the ability to start a business. While the endogenous variable, which is entrepreneurial intention is 83.22 in high conditions, the highest indicator is the business line itself while the lowest indicator is planning to start a business.

Because this study tests the model, the results of hypothesis testing carried out with the calculation process more than once, this is done to get into the research model proposed. Based on the simultaneous initial calculation, the effect of Locus of control (X1), Risk-Taking (X2) and Confidence (X3) obtained $\mathrm{R} 2=0.527, \mathrm{~F}=138,591(\mathrm{P}=0,000)$ significant testing. This means that Locus of control, Risk- Taking and Confidence have a positive effect on Entrepreneurial Intention, but after looking at the testing of each variable, there is an insignificant variable, namely risk-taking, as described in table 1 below.

Table 1. Effect of locus of control (X1) risk-taking (X2) and confidence (X3) Towards Entrepreneurial Intention.

\begin{tabular}{lllll}
\hline \multirow{2}{*}{ Variable } & Effect & & \multicolumn{2}{c}{ Total } \\
\cline { 2 - 4 } & direct & indirect X1 & indirect X2 & \\
\hline $\mathrm{X} 1$ & 0.0412 & - & 0.0357 & 0.0769 \\
$\mathrm{X} 2$ & 0.410 & 0.0357 & - & 0.4466 \\
\hline Total & & & & 0.5235 \\
\hline
\end{tabular}

Based on the results of hypothesis testing trimming is needed because there are variables that are not significant, then the variable is discarded and the recalculation process is carried out. The results are as follows.

Table 2. Anova.

\begin{tabular}{lllll}
\hline Model & F & Sig & R & R Square \\
\hline 2 & 205.794 & $0.000 \mathrm{a}$ & 0.724 & 0.524 \\
\hline
\end{tabular}

Based on table 2, the results of simultaneous testing, the effect of Locus of control (X1), and Confidence (X3) obtained $\mathrm{R} 2=0.524, \mathrm{~F}=205.794(\mathrm{P}=0.000)$ significant testing. This means that Locus of control, and Confidence have a positive effect on Entrepreneurial Intention, and the magnitude of the influence is $52.4 \%$ and the remaining $47.6 \%$ is influenced by other variables. Thus the more effective locus of control and confidence, the more positive the intention of entrepreneurship. Testing the hypothesis of each variable is explained as follows.

Table 3. Effect of locus of control (X1) and confidence (X3) towards entrepreneurial intention.

\begin{tabular}{lllll}
\hline Variable effect & $\begin{array}{l}\text { Path } \\
\text { coefis }\end{array}$ & t count & Sig & \\
& & & \\
\hline$(\mathrm{X} 1) \rightarrow(\mathrm{Y})$ & 0.203 & 5.463 & 0.000 & H0 reject \\
$(\mathrm{X} 3) \rightarrow(\mathrm{Y})$ & 0.641 & 17.279 & 0.000 & H0 reject \\
\hline
\end{tabular}

Table 4. Decomposition of results of calculation of direct, indirect effects and total influence.

\begin{tabular}{lllll}
\hline $\begin{array}{l}\text { Variable } \\
\text { Effect }\end{array}$ & Pathccoef & t count & Sig & \\
\hline$(\mathrm{X} 1) \rightarrow(\mathrm{Y})$ & 0.175 & 4.290 & 0.000 & H0 Reject \\
$(\mathrm{X} 2) \rightarrow(\mathrm{Y})$ & 0.077 & 1.586 & 0.113 & H0 Receipt \\
$(\mathrm{X} 3) \rightarrow(\mathrm{Y})$ & 0.604 & 13.828 & 0.000 & H0 Reject \\
\hline
\end{tabular}

Based on table 4, the structure model is as follows.

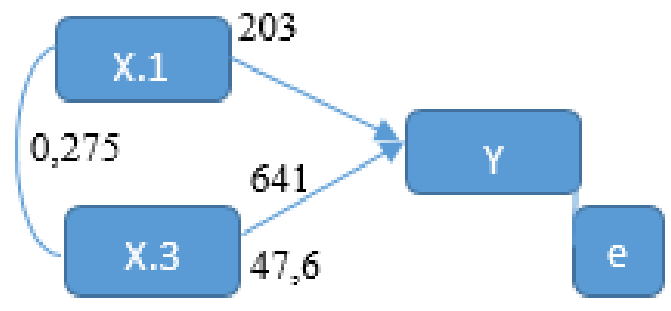

figure 2. Structure of the research model.

Information:

X.1 = Locus of control

$\mathrm{X} .3$ = Confidence

$\mathrm{Y}=$ Entrepreneurial intention

e. $=$ Other factors not examined

Entrepreneurial intention variable is explained by the influence of locus of control by 0.0769 , which means the higher locus $f$ control, the more positive the intention of entrepreneurship. Therefore locus of control is an important variable to be considered and improved, since locus of control as a form of entrepreneurial intention. This is in accordance with Rotter's opinion that a person has a belief about the causes of success and failure that they experience occur because of internal factors or external factors, which are [4]. [5] refer to self-confidence as an entrepreneurial characteristic and it is related to other psychological characteristics, such as locus of control, a tendency to take risks and tolerance for ambiguity. Based on the results of these studies, how important it is to improve locus of control, so that the results can equip students with entrepreneurial intentions obtained based on their expertise and are ready to take work in the community later with the quality of reliable human resources. However, the indicator that needs to be improved is lack of effort. This must be improved in learning through recitation activities. With patterns of learning recitation, students will be given the task of planning, so that the knowledge and skills they have will encourage entrepreneurial intentions, and entrepreneurial behavior.

Entrepreneurial intention variable is explained by the path of influence by self-confidence of 0.4466 means that the higher the confidence, the more positive the intention of entrepreneurship. Therefore self-confidence is an important variable to be considered and improved, because it is confident as a form of entrepreneurial intention. This is in accordance 
intentions. Based on these conclusions, it is advisable for entrepreneurial educators to increase locus of control through indicators that they don't like to try. This can be done through the provision of business planning tasks based on observations and interviews, so that the knowledge and skills possessed are the drivers of entrepreneurial intentions, which in turn will trigger entrepreneurial behavior. In order to improve the indicator of the ability to start a business. This can be done through entrepreneurship learning by providing business startup material, so students will be trained in managing the business. The research findings show that entrepreneurial intention is influenced by locus of control and self-confidence.

\section{REFERENCES}

[1] Kuratko, D.F. 2005. The emergence of entrepreneurship education: Development, trends and challenges. Entrepreneurship Theory and Practice 29(5): 577-597.

[2] Sexton, D.L. \& Kasarda, J.D. 1991. The State of the Art of Entrepreneurship. Boston, MA: PWS-Kent Publishing Co.

[3] Athayde, R. 2009. Measuring enterprise potential in young people. Entrepreneurship Theory and Practice 33(2): 481-500.

[4] Maimunah, S., Hendri, H., Rosli, N.S.M., Rafanoharana, S.C., Sari, K.R. \& Higashi, O. 2011. Strengthening community to prevent flood using participatory approach (a case of the Semarang city). Journal of International Development and Cooperation 18(2): 19-28.

[5] Ho, T.S. \& Koh, H.C. 1992. Differences in psychological characteristics between entrepreneurially inclined and non-entrepreneurially inclined accounting graduates in Singapore. Entrepreneurship, Innovation and Change: An International Journal 1: 243-54.

[6] Bandura, A. 1977. Self-efficacy: Toward a unifying theory of behavioral change. Psychological review 84(2): 191.

[7] Cromie, S. 2000. Assessing entrepreneurial inclinations: Some approaches and empirical evidence. European Journal of Work and Organizational Psychology 9(1): 7-30.

[8] Betz, N.E. \& Hackett, G 1986. Applications of self-efficacy theory to understanding career choice behavior. Journal of Social and Clinical Psychology 4(3): 279-289

[9] Giles, M. \& Rea, A. 1970 Career self-efficacy: An application of the theory of planned behavior. Journal of Occupational \& Organizational Psychology 73(3): 393-399

[10] Robinson, P.B., Stimpson, D.V., Huefner, J.C. \& Hunt, H.K. 1991. An attitude approach to the prediction of entrepreneurship. Entrepreneurship Theory and Practice 15: 1331

[11] Florin, J., Karri, R. \& Rossiter, N. 2007. Fostering entrepreneurial drive in business education: An attitudinal approach. Journal of Management Education 31(1): 17-42.

[12] Raposo, M., Pac, O.A. \& Ferreira, J. 2006. The potential entrepreneur profile - attributes and motivations of university students. Proceedings of IntEnt 2006 - Internationalizing Entrepreneurship Education and Training.

[13] Raposo, M., Pac, O.A. \& Ferreira, J. 2008a. Entrepreneur's profile: A taxonomy of attributes and motivations of university students. Journal of Small Business and Enterprise Development 15(2): 405-18.

[14] Lee, S., Lim, S. \& Pathank, R. 2006. Influences on students' attitudes toward entrepreneurship: A multi-country study. International Entrepreneurship Management Journal 2: 351-66.
Psychological approach consisting of locus of control and self-confidence has a positive effect on entrepreneurial 